\title{
Poemas de Miguel Hernández 1910-1942**
}

\author{
Tradução de
}

\author{
José Cláudio de Almeida Abreu
}

* HERNĀNDEZ, Miguel. Poemas de Amor, 2o edición. Madrid, Alianza Editorial, 1975.

* Miguel Hernández nasce na provincia de Alicante (Espanha) a 30 de outubro de 1910. Deixa aos 12 anos a escola para trabalhar com o rebanho de cabras de seu pai, postoreando e ordenhando. Em 1931 em Madri conhece Josefina Manresa, jovem aprendiz de costura, ao redor de quem girará como um satélite a vida do poeta: «Satélite de ti, no hago otra cosa». Verso definitivo que traduz confissão de amor perene. Josefina será com efeito a noiva, a mulher e a mãe dos filhos do poeta. Hernández em 1937 toma parte no Congresso de Escritores Anti-fascistas e visita oficialmente, com um grupo de intelectuais espanhóis, a Rússia. Em 1939, perseguido pela Guarda Civil Espanhola, tenta passar a Portugal por Huelva, porém é capturado pelos portugueses e entregue à polícia espanhola que o encarcera em Sevilha e depois em Madri. Na prisão escreve as «Nanas de la cebolla», na opinião de Concha Zardoya «la más trágica canción de cuna de la poesía española». Em 1941 é transferido para o Reformatório de Adultos de Alicante, em cuja enfermaria morre a 28 de março de 1942.

Obras: Perito en lunas (1933), El rayo que no cesa (1936), Viento del Pueblo (1937), etc. 
Tus cartas son un vino que me trastorna $\mathrm{y}$ son el único alimento para mi corazón.

Desde que estoy ausente no sé sino soñar, igual que el mar tu cuerpo, amargo igual que el mar.

Tus cartas apaciento metido en un rincón $\mathrm{y}$ por redil y hierba les doy mi corazón.

Aunque bajo la tierra mi amante cuerpo esté, escríbeme, paloma. que yo te escribiré.

Cuando me falte sangre, con zumo de clavel, y encima de mis huesos de amor, cuando papel. 
Tuas cartas são um vinho que me transtorna e são o único alento para o meu coração.

Desde que estou ausente só sei sonhar, como o mar teu corpo, amargo como o mar.

Tuas cartas apacento escondido em meu rincão e como aprisco e pasto lhes dou meu coração.

Sob a terra eu, corpo amante, um dia estarei, escreve-me, ainda assim, amor, que eu responderei.

Quando me faltar sangue, da flor com o mel, e sobre minha ossada amante, quando papel. 


\section{ME SOBRA EL CORAZŌN}

Hoy estoy sin saber yo no sé cómo, hoy estoy para penas solamente, hoy no tengo amistad, hoy sólo tengo ansias de arrancarme de cuajo el corazón y ponerlo debajo de un zapato.

Hoy reverdece aquella espina seca, hoy es día de llantos en mi reino, hoy descarga en mi pecho el desaliento plomo desalentado.

No puedo con mi estrella.

$\mathrm{Y}$ me busco la muerte por las manos mirando con cariño las navajas, y recuerdo aquel hacha compañera, $\mathrm{Y}$ pienso en los más altos campanarios para un salto mortal serenamente.

Si no fuera ¿por qué?... no sé por qué, mi corazón escribiría una postrera carta, una carta que llevo allí metida, haría un tintero de mi corazón, una fuente de sílabas, de adioses y regalos, $y$ ahi te quedas, al mundo le diría. 


\section{SOBRA-ME O CORAÇĀO}

Hoje estou sem saber eu não sei como hoje estou só para penas

hoje não tenho amigos, hoje só tenho ânsias

de arrancar-me inteiro o coração e pô-lo debaixo de um sapato.

Hoje reverdece aquele espinho seco, hoje é dia de prantos em meu reino, hoje descarrega em meu peito o desalento chumbo desalentado.

Não agüento minha estrela.

$\mathrm{E}$ procuro a morte pelas mãos

Olhando com carinho as navalhas,

e lembro-me daquele punhal companheiro, e penso nos mais altos campanários para um sereno salto mortal.

Se não fosse por quê?... não sei por que meu coração escreveria uma última carta, uma carta que trago aqui guardada, faria um tinteiro do meu coração, uma fonte de sílabas, de adeuses e legados, e um até breve diria ao mundo. 
Yo nací en mala luna.

Tengo la pena de una sola pena

que vale más que toda la alegría.

Un amor me ha dejado con los brazos caídos y no puedo tenderlos hacia más.

¿No veis mi boca qué desengañada, qué inconformes mis ojos?

Cuanto más me contemplo más me aflijo: cortar este dolor ¿con qué tijeras?

Ayer, mañana, hoy padeciendo por todo mi corazón, pecera melancólica, penal de ruiseñores moribundos.

Me sobra corazón. Hoy descorazonarme, yo el más corazonado de los hombres, y por el más, también el más amargo.

No sé por qué, no sé por qué ni cómo me perdono la vida cada día. 
Eu nasci em má lua.

Tenho a dor de uma só dor que vale mais que toda a alegria.

Um amor me deixou abatido

e não posso mais reagir.

Não vês como minha boca está desprezível, como estão disformes meus olhos?

Quanto mais me contemplo mais me aflijo: cortar esta dor com que tesoura?

Ontem, amanhã, hoje padecendo por tudo meu coração, aquário melancólico, prisão de rouxinóis enfermos.

Sobra-me o coração. Hoje me acovardo, eu entre os homens o mais carajoso, e por ser o mais, também o mais amargo.

Não sei por que, não sei por que nem como me perdôo cada dia a vida. 


\section{TRISTES GUERRAS}

Tristes guerras

si no es amor la empresa.

Tristes, tristes.

Tristes armas

si no son las palabras.

Tristes, tristes.

Tristes hombres

si no mueren de amores.

Tristes, tristes. 


\section{TRISTES GUERRAS}

\section{Tristes guerras}

se não é amor o fim.

Tristes, tristes.

Tristes armas

se não são as palavras.

Tristes, tristes.

Tristes homens

se não morrem de amores.

Tristes, tristes. 


\section{LLEGÔ CON TRES HERIDAS}

Llegó con tres heridas:

la del amor,

la de la muerte,

la de la vida.

Con tres heridas viene:

la de la vida,

la del amor,

la de la muerte.

Con tres heridas yo:

la de la muerte,

la de la vida,

la del amor. 


\section{CHEGOU COM TRES FERIDAS}

chegou com três feridas:

a do amor,

a da morte,

a da vida.

Com três feridas vem:
a da vida,
a do amor,
a da morte.

Com três feridas eu:
a da morte,
a da vida,
a do amor. 


\section{LA PENA HACE SILBAR, LO HE COMPROBADO}

La pena hace silbar, lo he comprobado, cuando el que pena, pena malherido, pena de desamparo desabrido, pena de soledad de enamorado.

¿Qué ruy-señor amante no ha lanzado pálido, fervoroso y afligido, desde la ilustre soledad del nido el amoroso silbo vulnerado?

¿Qué tórtola exquisita se resiste ante el silencio crudo y favorable a expresar su quebranto de viuda?

Silbo en mi soledad, pájaro triste, con una devoción inagotable, y me atiende la sierra siempre muda. 


\section{A DOR FAZ GRITAR, TENHO COMPROVADO}

A dor faz gritar, tenho comprovado, quando o que pena, pena malferido, pena de desamparo desabrido, pena de solidão de apaixonado.

Que rouxinol amante não há lançado com palidez, fervor e aflição do seu ninho da imensa solidão este amoroso grito, melindrado?

Que delicado pássaro resiste ao silêncio cruel e favorável a expressar seu pranto de viuvez?

Grito na solidão, pássaro triste, com uma devoção inesgotável e me ouve a montanha em sua mudez. 
SER ONDA, OFICIO, NIÑA, ES DE TU PELO

Ser onda, oficio, niña, es de tu pelo, nacida ya para el marero oficio; ser graciosa y morena tu ejercicio y tu virtud más ejemplar ser cielo.

¡Niña!, cuando tu pelo va de vuelo, dando del viento claro un negro indicio, enmienda de marfil y de artificio ser de tu capilar borrasca anhelo.

No tienes más que hacer que ser hermosa, ni tengo más festejo que mirarte, alrededor girando de tu esfera.

Satélite de ti, no hago otra cosa si no es una labor de recordarte.

- i Date presa de amor, mi carcelera! 
SER ONDA E OFICIO, MENINA, DE TEU CABELO

Ser onda é ofício, menina, de teu cabelo, já tão bem nascida para o marinho ofício; ser graciosa e morena é teu exercício e tua virtude mais exemplar o desvelo.

Menina, quando voar teus cabelos vejo dando do vento forte e claro um negro indício, mudar o rumo de marfim e de artifício de tua capilar borrasca é meu desejo.

Não tens que fazer senão seres desejada, nem tenho outro prazer que não seja mirar-te, ao redor girando de tua esfera de amor.

Satélite teu, não consigo fazer nada que não tenha por finalidade lembrar-te.

- Dá-te, minha carcereira, presa de amor. 